\title{
A taxonomic review of the Palpada ruficeps species group, with the description of a new flower fly from Colombia (Diptera: Syrphidae)
}

\author{
XIMO MENGUAL ${ }^{1} \&$ F. CHRISTIAN THOMPSON ${ }^{2}$ \\ ${ }^{1}$ Instituto de Investigación CIBIO (Centro Iberoamericano de la Biodiversidad), Universidad de Alicante, Apdo 99, E-03080, Alicante, \\ Spain.E-mail:xmengual@ua.es \\ ${ }^{2}$ Systematic Entomology Laboratory, PSI, Agricultural Research Service, U. S. Department of Agriculture, \\ NHB-0169 Smithsonian, Washington, D. C. 20560 USA. E-mail:chris.thompson@ars.usda.gov
}

\begin{abstract}
A new species of flower flies, Palpada prietorum Mengual spec. nov. (Diptera: Syrphidae: Eristalinae) is described from Cali, Colombia. The new species belongs to the ruficeps subgroup in the vinetorum species group. An identification key is provided for the species of the ruficeps subgroup, as well as a comparison of morphological diagnostic characters to separate these taxa. Fragments of the mitochondrial cytochrome c oxidase subunit I (COI) gene, the D2-3 region of the nuclear 28S rRNA gene and the nuclear internal transcribed spacer (ITS2) are supplied for two species, Palpada prietorum spec. nov. and Palpada ruficeps (Macquart, 1842).
\end{abstract}

Key words: Systematic, Diptera

\section{Introduction}

Flower flies of the subfamily Eristalinae (Diptera: Syrphidae) are among the most common and conspicuous flower flies. These flies are common pollinators almost wherever flowers are found, being absent only in truly arid areas and the Polar Regions. The larvae of eristaline flower flies are filter feeders in all kinds of aquatic media and are commonly called rat-tailed maggots. Occasionally these larvae are accidentally swallowed by humans, thus causing myiasis. Otherwise, the larvae contribute to the purification of water by filtering out microorganisms and other products. Flies of the subtribe Eristalina are currently placed into 16 genera and 400 species (Thompson, 2003).

Palpada Macquart, 1834 is a large group of tropical eristaline flies found only in the New World, belonging to the tribe Eristalini (Diptera: Syrphidae: Eristalinae). Palpada species are large flies, with a tuberculate laterally pilose face, with bare or pilose eyes, bare arista, petiolate cell R1, sinuate vein R4+5, and simple legs except for metafemur sometimes moderately swollen (Thompson 1972). The last comprehensive identification key for Palpada species was published in 1934 by C. H. Curran as a key to Eristalis Latreille, 1804, but including less than the half of the currently known Palpada species and many non Palpada species. Later, Lagrange (1987a, b; 1992a, b, c) revised the Argentine Palpada species. In the last catalog of Neotropical flower flies, 102 species were listed for Palpada (Thompson et al. 1976) and since that catalog 6 species have been described, many names reduced to synonyms or transferred to other genera (net 85 species) and some 24 species await description. Thompson (2003) provided a key to all the genera and groups of the subtribe Eristalina (Syrphidae: Eristalinae: Eristalini) as well as some nomenclatural notes for Palpada. The most recent study about Palpada species is Thompson (1999), where he described three new species from the scutellaris and vinetorum groups. Palpada species are found in the southern Nearctic and Neotropical Regions and a total 
of 85 species are recognized (Thompson, 2003). Three species groups were defined (Vockeroth in Thompson, 1981; also see Thompson 2003) based on morphological characters of the imagos: scutellaris group (Palpada sensu stricto), agrorum group (Gymnopalpada Vockeroth) and vinetorum group (Trichopalpada Vockeroth). The new species described here belongs to the vinteorum group, but with other three species differ from all other members of that group in having the wing completely bare, forming the ruficeps subgroup (Thompson 1999: 345). This subgroup and the included species presently known are separated in the below key.

Palpada flies are usually common and widespread. As an example, Palpada vinetorum ranges from Virginia in the north to northern Argentina in the south, and has been introduced and spread across the central Pacific, from the Society Islands to Samoa. In the ruficeps group, two of the species (bistellata and ruficeps) range from Costa Rica to Peru, and the third species (suprarufa) has been collected from 4 different localities in Ecuador at elevations from 2900 to 3300 meters. The new species (prietorum) described here is known only from one locality outside of Cali, Colombia. We have studied a number of collections of Palpada from Colombia without finding any additional material, so we speculate that this is a very narrow endemic and something unusual for these flies. Others now need to search the hill tops and test our hypothesis.

\section{Material and methods}

The morphological terminology follows Thompson (1999). Mitochondrial cytochrome c oxidase subunit I (COI) gene, the D2-3 region of the nuclear 28S rRNA gene and the nuclear internal transcribed spacer (ITS2) were sequenced for two species, Palpada prietorum and P. ruficeps. We followed the standard protocols to obtain DNA sequences (including the primers used) described in Mengual et al. (2006). Two paratype specimens were used in the molecular analyses. Only one or two legs were used to extract DNA as a potentially useful character for species identification as suggested by the DNA barcoding program (Tautz et al. 2003, Hebert et al. 2003, 2004a, b, Savolainen et al. 2005). Thus, the remains of both paratypes are deposited in CEUA as voucher specimens (see below for label data). Each analyzed specimen has a unique lab code that refers to a determined study (XP + number in these cases), with a prefix that indicates the collection where the specimen is deposited, e.g. CEUA. We also sequenced the DNA of one specimen of Palpada ruficeps (Macquart, 1842) (COLOMBIA, Dpto Valle del Cauca, Cali, 03²9.137’'N 76³3.596’'W, Cerro San Antonio, 2200 m.,1 male, 15.ii.2006, X. Mengual) and deposited as a voucher in CEUA (DNA voucher specimen CEUA_XP104), as it is the morphologically closest species to the new taxon.

Abbreviations: CEUA=Colección Entomológica de la Universidad de Alicante, CIBIO, Alicante, Spain; MUSENUV=Museo de Entomología de la Universidad del Valle, Cali, Colombia; USNM=National Museum of Natural History, Washington, D.C., USA.

\section{Systematic account}

Palpada prietorum Mengual, spec. nov.

Figs. 2, 5-7.

Holotype. COLOMBIA, Dpto Valle del Cauca, Cali, 03²9.137’'N 76³3.596'W, Cerro San Antonio, 2200 m.: male, 24.ii.2006, F.C. Thompson, deposited in USNM.

Paratypes. COLOMBIA, Dpto Valle del Cauca, Cali, 03²9.137’'N 76³3.596'W, Cerro San Antonio, 2200 m.: 1 male, 26.vii.2004, C. Prieto (USNM); 1 male, 04.viii.2004, C. Prieto (CEUA, DNA voucher specimen CEUA_XP117); 3 males, 15.ii.2006, X. Mengual (1 in CEUA, 2 in MUSENUV); 1 male, 15.ii.2006, X. Mengual (CEUA, DNA voucher specimen CEUA_XP118); 1 male, 15.ii.2006, C. Gutierrez (USNM). 
MALE - Head. Face yellow except some individuals dark brown along oral margin, golden pollinose and golden pilose laterally and ventrad of antenna; tubercle distinct, shiny and bare; gena broad, black, silverywhite pollinose (see figure 5); lunule golden; frontal triangle golden and black pilose, but mainly golden pilose; vertical triangle as long as eye contiguity, dull brownish pollinose, golden pilose; ocelli reddish; holoptic; eye golden pilose; antenna orange, black pilose on scape and pedicel; basoflagellomere brownish dorsally in some specimens; arista orange or brownish, bare; occiput silvery pilose and pollinose on ventral $2 / 3$, becoming golden pollinose and pilose on dorsal 1/3.

Thorax. Mostly black, grayish pollinose; postpronotum orange-brownish, orange pilose; scutum completely black, black pollinose, orange-reddish pilose; scutellum intense orange, orange pilose; postalar callus mainly black pilose, with yellow pile on posterior $1 / 4$ to $1 / 5$; pleurae dull grayish-black pollinose, entirely black pilose; dorsal calypter brownish black; ventral calypter light brown; halter pedicel pale; capitulum brownish; spiracular fringes brown; katepimeron black pilose; posterior anepimeron black pilose; dorsomedial anepimeron bare (figure 2).

Wing. Wing hyaline except blackish on anterobasal 2/3 (figure 6); tegula and basicosta black pilose; almost completely bare, microtrichia restricted to narrow vitta along medial area, from posterior to tip of cell $\mathrm{C}$ across cell Sc and R1 at level of base of cell R4+5 and across cell R and ending at vein M .

Legs. Coxae and trochanters black, black pollinose, black pilose; femora black, shiny except profemur and mesofemur sparsely black pollinose dorsolaterally; tibiae black, black pilose; tarsi brownish yellow to brownish black, orange pilose.

Abdomen. Dorsum mainly black, black-brownish pollinose, except 3rd and 4th terga with medial shiny fascia (figure 2); 1st tergum whitish-yellow pilose; 2nd tergum usually with 2 yellow-orange lateral maculae but very dark brown in some individuals, orange pilose in the anterior medial $1 / 2$, blackish-brown pilose in the posterior $1 / 2$ and lateral anterior 1/2; 3rd tergum dark brown pilose; rest of posterior terga whitish-yellow pilose; sterna black, black pollinose, white pilose; male genitalia (figure 7) shiny black, white pilose; surstylus with dorsal lobe strongly curved and arcuate, with tip densely microsetose; superior lobe broad, with apicoventral row of microdens and two strong lateral setae.

FEMALE: Unknown.

Length (3): body, 11.0-13.0 (12.0) mm; wing, 9.6-11.0 (10.3) mm.

Variation: As noted in the description, some individuals are much darker.

Etymology: The specific epithet refers to the family name of the first collector of the species, Carlos Prieto, and it is dedicated to him and his family for their hospitability and generosity during the senior author's stay in Cali.

Biology: Adults were collected hilltopping in the same place on four different occasions (July, 26th and August, 4th of 2004, and of February, 15th and 24th of 2006). On 24 February, they were flying with $P$. cosmia (Schiner, 1868), P. mexicana (Macquart, 1847) and P. ruficeps (Macquart, 1842), where the two former were much more abundant.

Differential diagnosis: Palpada prietorum belongs to a small group of species, the ruficeps subgroup, which has the wing bare or nearly so, but shares some characters with the other member of the vinetorum species group, e.g. ciliate metatibia with apicolateral dens (tooth), and the pilose posterior anepimeron. There are 4 species in this subgroup: bistellata (Hull, 1935), prietorum Mengual spec. nov., ruficeps (Macquart 1842) and suprarufa Thompson, 1999 (see figs. 1-4). Palpada prietorum is most similar to ruficeps but is a smaller and darker species, and can be separated as follows: 1) wing dark on anterobasal 2/3, not hyaline; 2) wing microtrichose in cell R1 in area from fork of RS to end of vein Sc, not bare; 3) tegula and basicosta black, not pale; 4) metacoxa black pilose, not white pilose; 5) mesotibia black pilose, not mostly white pilose; 6) postalar callus black pilose on at least the anterior $3 / 4$, not entirely orange pilose; 7) pleuron black pilose, not mostly or entirely pale pilose; 8) metasternum black pilose, not most white pilose; 9) 2nd and 3rd terga entirely dark pilose, mainly black pilose but more brownish orange anteromedially, not pale yellow pilose on basal $3 / 4$ (2nd) to $2 / 3$ (3rd). 


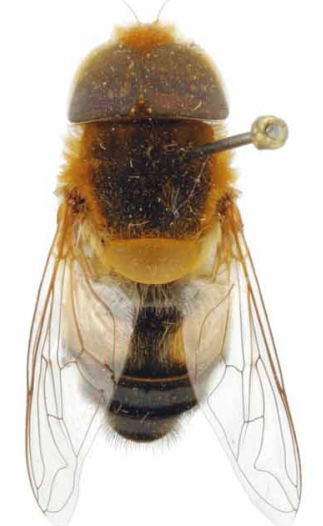

1

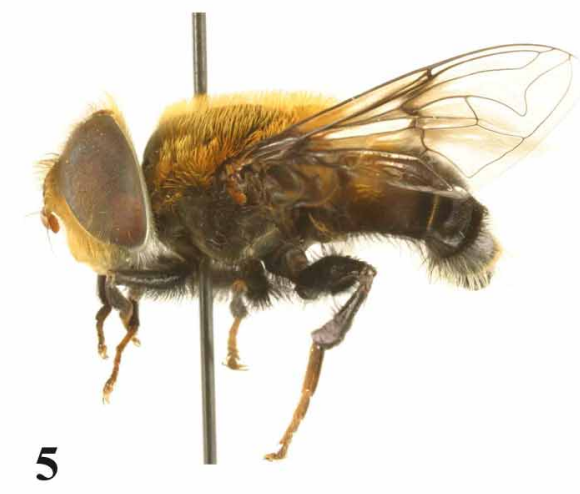

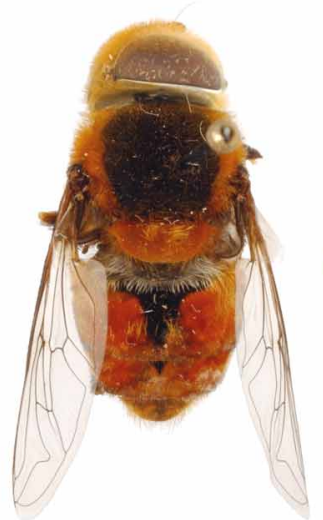

3

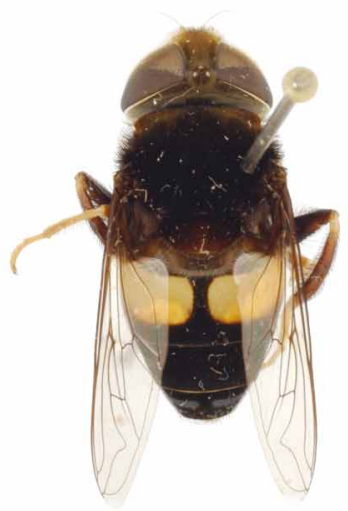

4

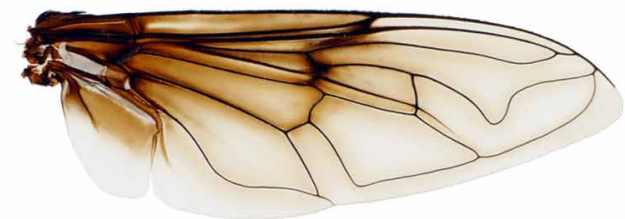

6
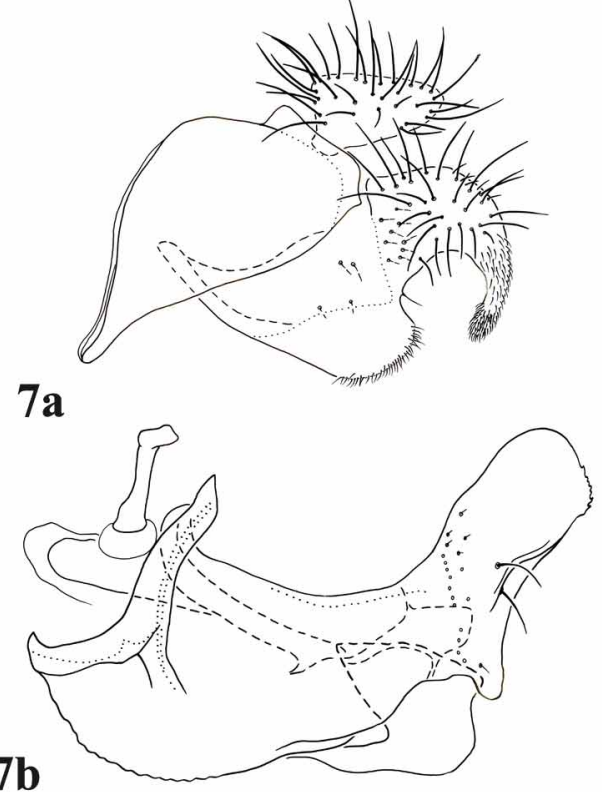

FIGURES 1-7. 1-4. Palpada habitus, dorsal. 1, P. ruficeps (Macquart). 2, P. prietorum Mengual, spec. nov. 3, $P$. suprarufa Thompson. 4, P. bistellata (Hull). 5-6. Palpada prietorum Mengual, spec. nov. 5, habitus, lateral. 6, wing, dorsal. 7. Palpada prietorum Mengual, spec. nov., male genitalia, lateral; a, 9th tergum and associated structure; b, 9th sternum and associated structures.

\section{Key to the species of the Palpada ruficeps subgroup}

1. Katepimeron bare; wing partially microtrichose, with at least some microtrichia on apical wing cells ....... other Palpada species 
- Katepimeron pilose; wing completely bare or almost, with only a few microtrichia medially, always bare apically.

2. Posterior anepimeron bare; metatibia always transverse apically, without dens, usually not ciliate; small flies, about $12 \mathrm{~mm}$ or less..... other Palpada species

- Posterior anepimeron pilose; metatibia with apicolateral dens (tooth), ciliate; large flies, usually about 18 mm (ruficeps subgroup).

3. Scutellum black, black pilose. Metatarsus pale orange; abdomen black except for large quadrate yellow macula on 2nd tergum (Costa Rica to Peru). bistellata (Hull)

- Scutellum pale, yellow to red or orange, pale pilose

4. Metatarsus pale, orange to red. 2nd thru 4th terga red except for narrow basomedial black vitta (Ecuador) suprarufa Thompson

- Metatarsus dark, brown to black; abdomen more extensively dark, 2nd tergum dark with basolateral pale yellow to orange or brownish-orange maculae; 3rd and 4th terga usually entirely dark.....

5. Pleuron entirely yellow to orange pilose; calypter orange; postalar callus orange pilose; wing entirely hyaline (Colombia to Bolivia) ruficeps (Macquart)

- Pleuron entirely black pilose; calypter brownish black on basal 1/2; postalar callus black pilose; wing blackish on anterobasal 2/3 (Colombia) prietorum Mengual spec. nov.

\section{Molecular markers}

The GenBank accession numbers for the obtained sequences are listed in Table 1. From the specimen P. prietorum [XP117], only 28S sequence could be amplified. The uncorrected pairwise distance between the two species of Palpada for the COI gene was $2.80 \%$, and the alignment by eye of the ITS2 sequences required 4 changes and 3 indels. On the other hand, the sequences of 28S gene for P. prietorum specimens XP117 and XP118 were identical, and they differed only $0.16 \%$ from the sequence of XP104, P. ruficeps. These results are in congruence with the expected mutational rate of the different gene fragments.

TABLE 1. Data on included specimens and GenBank accession numbers for obtained sequences.

\begin{tabular}{lllll}
\hline Taxon name & Lab code & $\begin{array}{l}\text { GenBank accession } \\
\text { number COI }\end{array}$ & $\begin{array}{l}\text { GenBank accession } \\
\text { number 28S }\end{array}$ & $\begin{array}{l}\text { GenBank accession } \\
\text { number ITS2 }\end{array}$ \\
\hline $\begin{array}{llll}\text { Palpada ruficeps (Macquart, 1842) } \\
\text { XP104 }\end{array}$ & EF127451 & EF127453 & EF127456 \\
Palpada prietorum Mengual spec.nov. XP117 & & EF127454 & \\
Palpada prietorum Mengual spec.nov. XP118 & EF127452 & EF127455 & EF127457 \\
\hline
\end{tabular}

\section{Acknowledgments}

The authors wish to thank Nancy Carrejo, Carlos Ruiz and Catalina Gutierrez of Sección de Entomología, Departmento de Biología, Universidad del Valle, Cali, Colombia, for organising the "Primer taller de identificación de Syrphidae (Diptera) del Neotrópico" and providing the facilities and support for our work in Colombia. We are grateful to Santos Rojo of CIBIO, Universidad de Alicante, Spain, for providing economic support for the senior author.

We thank our technical support team: Gary Ouellette for figs $1-4$ and 5 as well as for preparing the final plate and Diana Marques for fig 7. 
Thanks are also due to Gunilla Ståhls, Finnish Museum of Natural History, Helsinki, Finland; M. Alma Solis, Matthew Buffington and Allen Norrbom, Systematic Entomology Laboratory, USDA, Washington, for their critical review of the manuscript.

\section{References}

Curran, C.H. (1934) Diptera of Kartabo, Bartica District, British Guiana. Bulletin of the American Museum of Natural History, 66, 287-532.

Hebert, P.D.N., Cywinska, A., Ball, S.L. \& deWaard, J.R. (2003) Biological identifications through DNA barcodes. Proceedings of the Royal Society of London B, 270, 313-322.

Hebert, P.D.N., Penton, E.H., Burns, J.M., Janzen, D.H., \& Hallwachs, W. (2004a) Ten species in one: DNA barcoding reveals cryptic species in the Neotropical skipper butterfly Astraptes fulgerator. Proceedings of the National Academy of Sciences of the United States of America, 101, 14812-14817.

Hebert, P.D.N., Stoeckle, M.V., Zemiak, T.S. \& Francis, C.M. (2004b) Identification of birds through DNA barcodes. PloS Biology, 2, e312, 1657-1663.

Hull, F.M. (1935) Some undescribed species of Eristalis from North America in the United States National Museum. Journal of the Washington Academy of Sciences, 25, 326-331.

Lagrange, E.B. (1987a) Notas sobre el género Palpada Macquart, 1834 (Insecta, Diptera, Syrphidae). Neotropica, 32 [1986], 97-103.

Lagrange, E.B. (1987b) Una nueva especie del genero Palpada Macquart, 1834 (Insecta, Diptera, Syrphidae). Neotropica, 33, 41-44.

Lagrange, E.B. (1992a) Revision de las especies Argentinas del Grupo agrorum del género Palpada Macquart, 1834 (Diptera, Syrphidae). Revista de la Associacion de Ciencias Naturales del Litoral, 21 [1990], 3-40.

Lagrange, E.B. (1992b) Revision de las especies Argentinas del grupo scutellaris del genero Palpada Macquart, 1834 (Diptera, Syrphidae). Neotropica, 35, 15-34.

Lagrange, E.B. (1992c) Revision de las especies argentinas del grupo vinetorum del género Palpada (Diptera, Syrphidae). Revista Sociedad Entomologica Argentina, 50 (1991), 45-166.

Lagrange, E.B. (in press) Claves para la identificación de las especies argentinas del grupo scutellaris del género Palpada (Diptera, Syrphidae). Revista Sociedad Entomologica Argentina [cited in Lagrande 1987b]

Macquart, J. (1842) Diptères exotiques nouveaux ou peu connus. Mèmoires de la Société Nationale des Sciences, de l'Agriculture et de Arts de Lille, 1841(1), 65-200, 22 pls.

Mengual, X., Ståhls, G., Vujić, A. \& Marcos-García, M.A. (2006) Integrative taxonomy of Iberian Merodon species (Diptera, Syrphidae). Zootaxa 1377: 1-26.

Savolainen, V., Cowan, R.S., Vogler, A.P., Roderick, G.K. \& Lane, R. (2005) Towards writing the encyclopaedia of life: an introduction to DNA barcoding. Philosophical Transactions of the Royal Society of London B Biological Sciences, 360 (1462), 1805-1811.

Tautz, D., Arctander, P., Minelli, A., Thomas, R.H. \& Vogler, A.P. (2003) A plea for DNA taxonomy. Trends in Ecology and Evolution, 18, 70-74. (doi:10.1016/S0169-5347(02)00041-1.)

Thompson, F.C. (1972) A contribution to a generica revision of the Neotropical Milesinae (Diptera: Syrphidae). Arquivos de Zoologia, 23, 73-215.

Thompson, F.C. (1981) The Flower Flies of the West Indies (Diptera: Syrphidae). Memoirs of the Entomological Society of Washington 9, $200 \mathrm{pp}$.

Thompson, F.C. (1999) A key to the genera of the flower flies (Diptera: Syrphidae) of the Neotropical Region including descriptions of new genera and species and a glossary of taxonomic terms used. Contributions on Entomology, International 3: 321-378.

Thompson, F.C. (2003) Austalis, a new genus of flower flies (Diptera: Syrphidae) with revisionary notes on related genera. Zootaxa, 246, 19 pp.

Thompson, F.C., Vockeroth, J.R. \& Sedman, Y.S. (1976) Family Syrphidae. A catalogue of the Diptera of the Americas South of the United States, 46, $195 \mathrm{pp}$.

Flower flies are pollinators of flowering plants and their rat-tailed maggots are aquatic filter-feeders. Hence, they play a critical role in maintaining diversity in the environment and some have been adapted to pollinated greenhouse crops. A species new to science related to these greenhouse pollinators was discovered in Colombia. Illustrations and DNA barcodes are provided so that this species can be readily compared and identified by researchers. This information will be useful to scientists, conservationists, and action agency identifiers / regulatory personnel at ports. 